\title{
Baccaurea racemosa (Reinw. ex Blume) Müll. Arg. pulp: a potential natural antioxidant
}

\author{
${ }^{1}$ Permatasari, L., ${ }^{1}$ Riyanto, S. and ${ }^{1,2 *}$ Rohman, A. \\ ${ }^{I}$ Department of Pharmaceutical Chemistry, Faculty of Pharmacy, Universitas Gadjah Mada, Yogyakarta \\ 55281, Indonesia \\ ${ }^{2}$ Institute of Halal Industry and Systems (IHIS), Universitas Gadjah Mada, Yogyakarta 55281, Indonesia
}

\begin{abstract}
Article history:
Received: 16 April 2019

Received in revised form: 2

June 2019

Accepted: 5 June 2019

Available Online: 9 June

2019
\end{abstract}

Keywords:

Kepundung,

Baccaurea racemosa,

Antioxidant activity,

Total phenolic content,

Total flavonoid content

DOI:

https://doi.org/10.26656/fr.2017.3(6).165

\begin{abstract}
Baccaurea racemosa (Reinw. ex Blume) Müll. Arg. is a fruit widely grown in Indonesia locally known as 'kepundung'. Some of genus Baccaurea has potential to be developed as a natural antioxidant. However, the antioxidant activity of $B$. racemosa pulp has not been published. This study is aimed to (i) explore the antioxidant activity, (ii) measure the total phenolic and flavonoid contents, and (iii) investigate the correlation of antioxidant activity of extract and fractions of $B$. racemosa pulp with their total phenolic and flavonoid contents. Fresh $B$. racemosa pulp was macerated with methanol to obtained methanolic extract. The methanolic extract was partitioned using n-hexane followed dichloromethane and ethyl acetate. This study revealed that ethyl acetate fraction has the highest antioxidant activity with the scavenging activity of free radical 2,2-diphenyl-1-picrylhydrazyl (DPPH) and 2,2'-Azinobis(3-etylbenzthiazoline)-6-sulfonic acid (ABTS) with values $\mathrm{IC}_{50} 127.155 \pm 4.311 \mathrm{ug} / \mathrm{mL}$ and $108.155 \pm 6.455 \mathrm{mM}$ trolox equivalent $/ 100 \mathrm{mg}$ dry extract respectively. However, the highest antioxidant activity using $\beta$-carotene bleaching (BCB) assay is the methanolic extract with value $36.898 \pm 13.240 \%$. Furthermore, the ethyl acetate fraction has the highest total phenolic content (TPC) and total flavonoid content (TFC) with values $42.975 \pm 1.978 \mathrm{mg}$ gallic acid equivalent/g dry extract (mg GAE ${ }^{-1}$ dry extract) and $122.813 \pm 1.604 \mathrm{mg}$ rutin equivalent/g dry extract (mg RE ${ }^{-1}$ dry extract) respectively. TPC and TFC of B. racemosa pulp have a significant correlation with ABTS free radical scavenging activity. In this current study, it was discovered that ethyl acetate fraction of B. racemosa pulp can be developed to be a natural antioxidant.
\end{abstract}

\section{Introduction}

Free radical is a reactive and unstable compound because it can attract the electron from another molecule (Lobo et al., 2010). It will cause a chain reaction and increase the amount of free radical. The high level of free radical in our body is dangerous for health because it can cause many kinds of diseases, such as Alzheimer, rheumatoid arthritis, aging, cataract and even cancer (Pham-Huy et al., 2008). Free radical can be overcome with antioxidant. Naturally, the human body produces antioxidant such as superoxide dismutase (SOD), glutathione peroxidase, and catalase (Zadak et al., 2009). Nevertheless, antioxidant from the outside is needed due to unbalance amount of antioxidant and free radical in the body. Synthetic antioxidant such as Buthyl Hydroxy Toluene (BHT) and Buthyl Hydroxy Anisole (BHA) are developed. However, both of them was reported to cause cancer in mouse (Race, 2009; Fitri, 2013). Because of this problem, there is a need to identify more effective dan safety antioxidant from a natural resource.

Kepundung, Baccaurea racemosa a fruit widely grown in Indonesia. The fruit of $B$. racemosa ripens from December until March. The leaves of B. racemosa have reported containing the activity of antioxidant with $91.23 \pm 0.02 \%$ scavenging of DPPH free radical (Wulansari and Chairul, 2011). Leaves and bark of $B$. racemosa have reported not containing alkaloid but containing flavonoid (Ismail et al., 2010). Other genus of Baccaurea have the potential as a medicine plant because it contains secondary metabolites such as alkaloid, flavonoid, antosianin, carotenoids, and phenolic which was commonly used as antioxidant, anticancer and antimicrobial (Gunawan et al., 2016). The pulps of Baccaurea angulata contain total phenolic and flavonoid that has a high correlation with its antioxidant activity with a correlation coefficient $>0.99$. However, there is no report about activity antioxidant from $B$. racemosa pulp and its correlation with phenolic and flavonoid total 
contents.

The purpose of our study was to explore for the first time the antioxidant activity of the methanolic extract, nhexane, dichloromethane, ethyl acetate and water fraction of $B$. racemosa pulp through $\beta$-Carotene Bleaching (BCB) assay, scavenging activity of free radical of DPPH and ABTS. Besides that, this study was aimed to quantify the total phenolic and flavonoid content of extract and fractions of B. racemosa pulp and to investigate the correlation between their total phenolic and flavonoid content with their antioxidant activity.

\section{Materials and methods}

\subsection{General experimental procedures}

2,2-diphenyl-1-picrylhydrazyl (DPPH), 2,2'-Azinobis(3-ethylbenzthiazoline)-6-sulfonic acid (ABTS), Trolox, quercetin, rutin, gallic acid, linoleic acid, $\beta$ carotene and Tween 20 were obtained from Sigma (Aldrich, USA). Folin-Ciocalteu, methanol, chloroform, dichloromethane, n-hexane and other pro-analytical grade solvent and reagent were purchased from Merck (Darmstadt, Germany). The B. racemosa pulp was obtained from Limbungan village, Gunung Sari, Lombok Barat, West Nusa Tenggara, Indonesia. B. racemosa was authenticated by I Gde Merthe (senior lecturer in Plant Taxonomy) in Laboratory of Biology, Faculty of Mathematics and Science, Mataram University, West Nusa Tenggara, Indonesia.

\subsection{Preparations of sample}

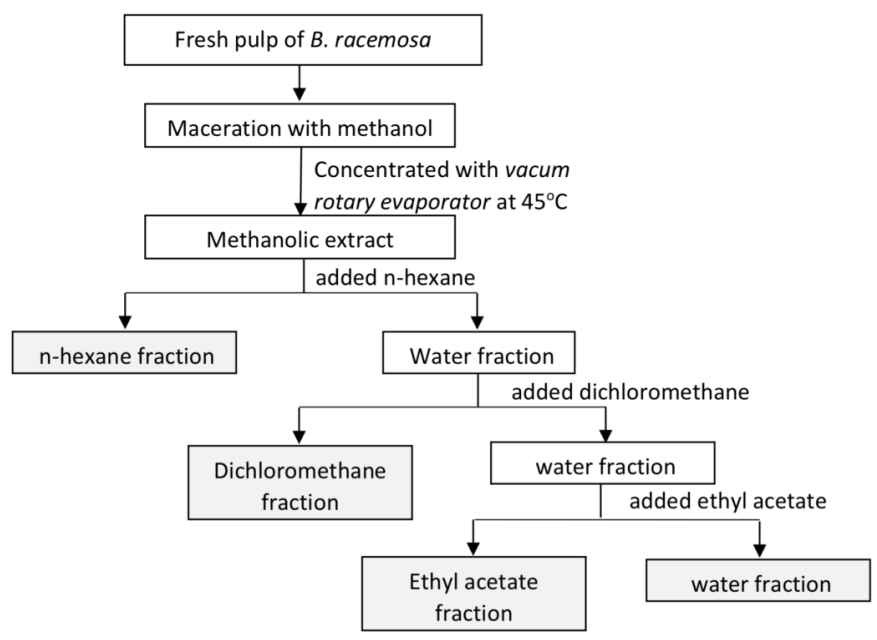

Figure 1. Extraction and fractionation step of B. racemosa pulp

The fruit of $B$. racemosa was washed with tap water. Seed and peel were separated from the pulp. The pulp was then stored in the freezer for $24 \mathrm{hrs}$. The $4.89 \mathrm{~kg} B$. racemosa pulp was blended with $4 \mathrm{~L}$ analytical grade of methanol and was extracted by maceration method for 3 days and re-maceration for 2 days. The mixture was filtered and concentrated using vacuum rotary evaporator at $45^{\circ} \mathrm{C}$ to obtain the methanolic extract of B. racemosa pulp. It was then fractioned using n-hexane, followed by dichloromethane and ethyl acetate to obtain n-hexane, dichloromethane, ethyl acetate and water fractions. The extract and all fractions were subjected in the following assays. The scheme of extraction and fractionation of $B$. racemosa pulp was illustrated in Figure 1.

\subsection{DPPH free radical scavenging assay}

The method to determine DPPH free radical scavenging activity was according to Kikuzaki et al. (2002) with slight modifications. The solution of DPPH $0.4 \mathrm{mM}$ was prepared by dissolving $15.8 \mathrm{mg}$ of DPPH with $100 \mathrm{~mL}$ of methanol p.a and then $1 \mathrm{~mL}$ of this solution was mixed with $4 \mathrm{~mL}$ of extract, fractions and quercetin (standard) at different concentration. A control was prepared with adding $1 \mathrm{~mL}$ of DPPH $0.4 \mathrm{mM}$ with 4 $\mathrm{mL}$ of methanol p.a. They were shaken and stand at room temperature for 30 mins. The absorbance of the solutions were measured at $515.5 \mathrm{~nm}$ with methanol as blank using UV-Visible spectrometer (Shimadzu 1800). The DPPH free radical scavenging activity of the sample was calculated using the following equation:

DPPH Scavenging Activity $(\%)=\frac{\text { Control absorbance-sample absorbance }}{\text { control absorbance }} \times 100 \%$

\subsection{ABTS radical scavenging activity}

The method to determine ABTS free radical scavenging activity was according to Aktumsek et al. (2013) with slight modifications. Solutions of ABTS 7 $\mathrm{mM}$ and natrium persulphate $2.45 \mathrm{mM}$ were mixed with ratio $1: 1$. The mixture was left for $12-16 \mathrm{hrs}$ at room temperature. Before assay, the mixture was diluted with methanol until it absorbance of $0.700 \pm 0.02$ at $734 \mathrm{~nm}$. Samples $(300 \mu \mathrm{L})$ and $3 \mathrm{~mL}$ of ABTS solution were mixed and were left for 30 mins at room temperature. Their absorbance was read at $734 \mathrm{~nm}$ using UV-Visible spectrometer (Shimadzu 1800). The ability of samples to scavenge the ABTS radical was expressed as $\mathrm{mM}$ Trolox equivalent/100 mg dry extract $(\mathrm{mM} \mathrm{TE} / 100 \mathrm{mg}$ dry extract).

\section{$2.5 \beta$-Carotene Bleaching (BCB)}

The method of measurement activity samples of BCB was according to Maisarah et al. (2013) with modifications. The $\beta$-carotene $(0.2 \mathrm{mg} / \mathrm{mL}$ in chloroform) $1 \mathrm{~mL}, 0.2 \mathrm{~mL}$ tween 20 , and $0.02 \mathrm{~mL}$ linoleic acid were mixed. The chloroform in the mixture was evaporated using vacuum rotary evaporator at $40^{\circ} \mathrm{C}$ and followed by the addition $100 \mathrm{~mL}$ deionized water with vigorous shaking to form an emulsion of $\beta$ carotene. The solution $(3.5 \mathrm{~mL})$ was added with $200 \mu \mathrm{L}$ sample, quercetin (standard) and methanol (control). The 
mixture was incubated in water bath at $50^{\circ} \mathrm{C}$ for 80 mins. The absorbance was measured at 20 mins interval at 470 nm using UV-Visible spectrometer (Shimadzu 1800) with emulsion without $\beta$-carotene as a blank. The antioxidant activity of samples was calculated using the equation:

$$
\% \mathrm{AA}=\frac{\mathrm{dr} \text { control }-\mathrm{dr} \text { sample }}{\mathrm{d} \text { control }} \times 100
$$

Where $\mathrm{dr}=$ degradation rate of $\beta$-carotene; $\mathrm{Ao}=$ absorbance sample at time 0 ; $A t=$ absorbance sample at 80 mins of incubation; and $\mathrm{AA}=$ antioxidant activity.

\subsection{Total phenolic content (TPC)}

Sample (30 uL) was added with $0.4 \mathrm{~mL}$ FolinCiocalteu reagent and was left for 5 mins. The mixture was added with $4.0 \mathrm{~mL}$ of $\mathrm{Na}_{2} \mathrm{CO}_{3} 7 \%$ and was followed by adding aquabidest. The solution was left for $2 \mathrm{hrs}$ and was read the absorbance at $750 \mathrm{~nm}$ using UV-Visible spectrometer (Shimadzu 1800) (Chun et al., 2003). The total phenolic contents were revealed as $\mathrm{mg}$ gallic acid equivalent/ $g$ dry extract (mg GAE $\mathrm{g}^{-1}$ dry extract).

\subsection{Total flavonoid content (TFC)}

Sample $(300 \mu \mathrm{L})$, aquabidest $4.0 \mathrm{~mL}$ and $0.30 \mathrm{~mL}$ $\mathrm{NaNO}_{2} 10 \%$ were mixed and they were left for 6 mins. The mixture was added with $0.30 \mathrm{~mL} \mathrm{AlCl}_{3} 10 \%$ and then left during 5 mins. The solution was added with 4.0 $\mathrm{mL} \mathrm{NaOH} 10 \%$ and $1.1 \mathrm{~mL}$ aquabidest. The absorbance was read at $510 \mathrm{~nm}$ using UV-Visible spectrometer (Shimadzu 1800) after incubation for 15 mins at room temperature. The flavonoid total contents of samples were revealed as $\mathrm{mg} \mathrm{RE} \mathrm{g}^{-1}$ extract (Chang et al., 2002).

\subsection{Statistical analysis}

Statistical analysis was conducted using the windows software of Statistical Package for Social Sciences (SPSS, version 22). The statistical analysis of antioxidant activity, TPC and TFC of B. racemosa were using oneway analysis of variance (ANOVA) followed by Tukey's honestly significant different (HSD). The significances of samples were accepted at $p<0.05$. Meanwhile, the correlation of various result of antioxidant activity of $B$. racemosa pulp with their TPC and TFC was revealed using Pearson correlation test with significances $\mathrm{p}<0.05$ and $\mathrm{p}<0.01$.

\section{Results and discussion}

\subsection{DPPH free radical scavenging activity}

Samples showed dose-dependent inhibition DPPH free radical. Elevating the concentration of racemosa pulp was clearly increasing antioxidant activity on inhibiting the DPPH free radical (Table 1). $\mathrm{IC}_{50}$ values of scavenging activity of DPPH free radical of extract and fractions can be ranked as ethyl acetate fraction $<$ methanol extract $<$ water fraction $<$ n-hexane fraction $<$ dichloromethane fraction (Table 1). Ethyl acetate fraction had the best results of antioxidant activity among the methanolic extracts and several fractions. The scavenging of DPPH radical estimated that there was a hydroxyl group in the components of ethyl acetate fraction of $B$. racemosa pulp which can donate its electron to the DPPH radical. Ethyl acetate is the semi-polar solvent that tends to extract aglycon, glycoside compounds, and flavonoid. These compounds have hydroxyl groups that are directly connected to chromophore so they can stabilize these compounds when they donate its electron to DPPH free radical. Meanwhile, n-hexane has low DPPH free radical scavenging activity because n-hexane is the non-polar solvent which extracts the lignin, lipid, less alkaloid and sterol (Widyawati et al., 2015). Dichloromethane is the lowest scavenging activity of DPPH free radical because it dissolves the fatty acid (Cequier-Sánchez et al., 2008). These compound does not have hydroxyl group so the DPPH radical cannot be stabilized. The DPPH radical scavenging activity was reported in the several species of genus Baccaurea, such as pulp of Baccaurea lanceolata and leaves of Baccaurea ramifolia (Dey and Pal, 2015; Hadi et al., 2015).

\subsection{ABTS free radical scavenging activity}

The ABTS was oxidated by potassium persulphate to generated cation radical of ABTS $\left(\mathrm{ABTS}^{+}\right)$. ABTS radical scavenging activity was calculated with trolox equivalency activity calculated (TEAC) (Cerretani and Bendini, 2010). The trolox equivalency values of extract and fractions of $B$. racemosa pulp were in order of ethyl acetate fraction $>$ n-hexane fraction $>$ dichloromethane fraction $>$ methanol extract $>$ water fraction (Figure 2). The higher the trolox equevalency of the sample, the higher the capacity of the sample to scavenge the activity of ABTS radical. The ABTS radical scavenging activity of the extract was reported that the ethyl acetate fraction had the highest antioxidant activity with the value of $108.155 \pm 6.455 \mathrm{mM}$ trolox equivalent/100 mg dry extract (Figure 2). The capacity of ethyl acetate fraction of $B$. racemosa pulp to scavenge the ABTS free radical was due to the compounds extracted in ethyl acetate fraction to have hydrogen that can stabilize the ABTS free radical. Meanwhile, the $\mathrm{n}$-hexane fraction has the highest ABTS free radical scavenging activity compared to methanol extract and water fraction because the nhexane fraction contained a lipophilic compound which can participate to neutralize the free radical (Gali and 
Table 1. DPPH free radical scavenging activity of $B$. racemosa pulp

\begin{tabular}{|c|c|c|c|}
\hline B. racemosa fraction & Concentration $(\mu \mathrm{g} / \mathrm{mL})$ & Percent inhibition $(\% \pm \mathrm{SD})$ & $\mathrm{IC}_{50} \bar{X} \pm \mathrm{SD}(\mu \mathrm{g} / \mathrm{mL})$ \\
\hline \multirow{5}{*}{ n-hexane fraction } & 40 & $9.040 \pm 3.261$ & \multirow{5}{*}{$948.710 \pm 29.344^{\mathrm{d}}$} \\
\hline & 280 & $19.191 \pm 3.022$ & \\
\hline & 520 & $30.125 \pm 2.502$ & \\
\hline & 760 & $42.065 \pm 2.954$ & \\
\hline & 1000 & $51.813 \pm 1.159$ & \\
\hline \multirow{5}{*}{ Dichloromethane fraction } & 80 & $9.268 \pm 3.112$ & \multirow{5}{*}{$1141.0698 \pm 151.184^{\mathrm{e}}$} \\
\hline & 560 & $33.659 \pm 3.549$ & \\
\hline & 1040 & $49.918 \pm 1.544$ & \\
\hline & 1520 & $60.610 \pm 3.189$ & \\
\hline & 2000 & $66.666 \pm 4.103$ & \\
\hline \multirow{5}{*}{ Ethyl acetate fraction } & 40 & $26.349 \pm 1.263$ & \multirow{5}{*}{$127.155 \pm 4.311^{\mathrm{b}}$} \\
\hline & 80 & $37.410 \pm 1.242$ & \\
\hline & 120 & $50.321 \pm 1.342$ & \\
\hline & 160 & $61.193 \pm 0.880$ & \\
\hline & 200 & $65.949 \pm 1.903$ & \\
\hline \multirow{5}{*}{ Water fraction } & 90 & $15.037 \pm 3.138$ & \multirow{5}{*}{$402.228 \pm 8.748^{\mathrm{c}}$} \\
\hline & 180 & $28.608 \pm 4.086$ & \\
\hline & 270 & $38.680 \pm 2.611$ & \\
\hline & 360 & $45.856 \pm 0.595$ & \\
\hline & 450 & $53.019 \pm 1.160$ & \\
\hline \multirow{5}{*}{ Methanolic extract } & 60 & $16.706 \pm 4.289$ & \multirow{5}{*}{$391.790 \pm 6.130^{c}$} \\
\hline & 180 & $32.225 \pm 0.480$ & \\
\hline & 300 & $44.299 \pm 0.943$ & \\
\hline & 420 & $54.394 \pm 1.133$ & \\
\hline & 540 & $60.570 \pm 1.684$ & \\
\hline \multirow{5}{*}{ Quercetin } & 1.5 & $24.446 \pm 0.615$ & \multirow{5}{*}{$2.995 \pm 0.080^{\mathrm{a}}$} \\
\hline & 2 & $32.602 \pm 2.085$ & \\
\hline & 2.5 & $43.881 \pm 1.586$ & \\
\hline & 3 & $49.143 \pm 0.737$ & \\
\hline & 3.5 & $58.365 \pm 2.314$ & \\
\hline
\end{tabular}

Values are expressed as mean $\pm \mathrm{SD}, \mathrm{n}=3$. Same alphabet superscripts within the same column indicate no significant difference ( $p>0.05)$ which measured with Tukey's HSD test. Quercetin as the positive control.

Bedjou, 2019). The other species of Baccaurea, the Baccaurea angulata was reported to have ABTS radical scavenging activity (Ahmed et al., 2015).

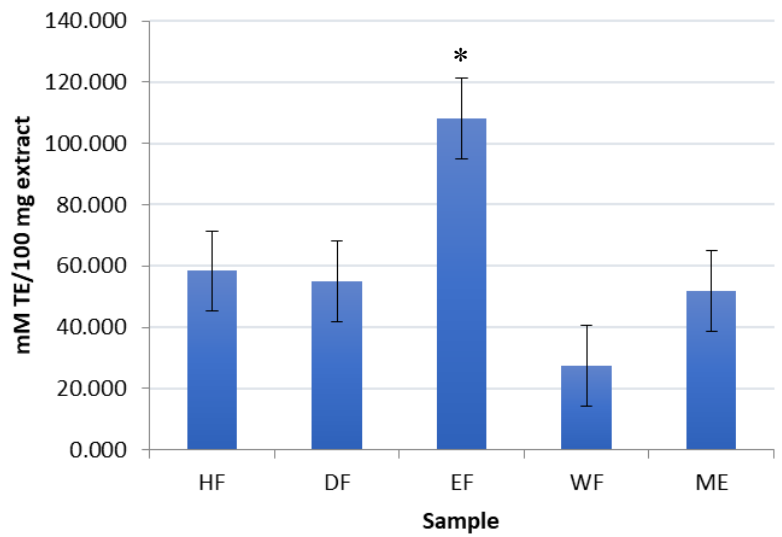

Figure 2. Scavenging activity of Baccaurea racemosa pulp on ABTS free radical. $n$-hexane fraction (HK), dichloromethane fraction (DK), Ethyl Acetate Fraction (EF), Water Fraction (WF), Methanolic extract (ME).

*significantly different with other sample $(p>0.05)$ which measured with Tukey's HSD test. Values are expressed as means \pm SD $(n=3)$.

\section{$3.3 B C B$}

Lipid membrane commonly consists of linoleic acid that is unsaturated fatty acid. Linoleic acid is a target of lipid peroxidation which can describe the lipid peroxidation of lipid membrane (Tchimene et al., 2016). The curve of the degradation rate of $\beta$-carotene after 80 mins incubation was shown in Figure 3. It showed that quercetin has a high capacity to inhibit BCB followed by $\mathrm{n}$-hexane fraction and methanolic extract. They exhibited a stabilization of $\beta$-carotene absorbance after incubation for 80 mins. The slower the degradation rate of the sample, the higher the antioxidant activity of the sample. The values of degradation rate and percentage of antioxidant activity of BCB were tabulated in Table 2. It showed that the percentage of antioxidant activity of extract and fractions were in the following order of methanolic extract $>$ n-hexane fraction $>$ ethyl acetate fraction $>$ dichloromethane fraction $>$ water fraction. Methanolic extract of $B$. racemosa pulp has a higher percentage of antioxidant activity than other fraction because of polyphenol compounds tends to dissolve in 
Table 2. Degradation rate and percentage of antioxidant activity of various $B$. racemosa

\begin{tabular}{ccc}
\hline Extract & $\mathrm{dr}$ (degradation rate) & Percentage of Antioxidant Activity (\%AA) \\
\hline n-hexane fraction & $0.015 \pm 0.0039^{\mathrm{ab}}$ & $31.276 \pm 14.085^{\mathrm{ab}}$ \\
Dichlorometane fraction & $0.017 \pm 0.0039^{\mathrm{abc}}$ & $22.538 \pm 15.207^{\mathrm{ab}}$ \\
Ethyl acetate fraction & $0.016 \pm 0.0002^{\mathrm{abc}}$ & $23.938 \pm 4.786^{\mathrm{ab}}$ \\
Water fraction & $0.019 \pm 0.0008^{\mathrm{bc}}$ & $10.604 \pm 8.524^{\mathrm{b}}$ \\
Methanolic extract & $0.014 \pm 0.0030^{\mathrm{a}}$ & $36.898 \pm 13.239^{\mathrm{a}}$ \\
Quercetin & $0.012 \pm 0.0033^{\mathrm{a}}$ & $44.116 \pm 14.750^{\mathrm{a}}$ \\
Control & $0.021 \pm 0.0012^{\mathrm{c}}$ & - \\
\hline
\end{tabular}

Values are expressed as mean $\pm \mathrm{SD}, \mathrm{n}=3$. Same alphabet superscripts within the same column indicate no significant difference ( $\mathrm{p}>0.05)$ which measured with Tukey's HSD test. Quercetin as the positive control.

Table 3. Total phenolic and flavonoid content of B. racemosa pulp

\begin{tabular}{|c|c|c|}
\hline Extract & TPC (mg GAE $\mathrm{g}^{-1}$ dry extract) & TFC (mg RE g ${ }^{-1}$ dry extract) \\
\hline n-hexane fraction & $27.481 \pm 0.304^{b}$ & NA \\
\hline Dichlorometane fraction & $26.615 \pm 1.393^{\mathrm{b}}$ & NA \\
\hline Ethyl acetate fraction & $42.975 \pm 1.978^{\mathrm{a}}$ & $122.813 \pm 1.604^{\mathrm{a}}$ \\
\hline Water fraction & $13.538 \pm 0.473^{\mathrm{c}}$ & $32.798 \pm 2.500^{\mathrm{c}}$ \\
\hline Methanolic fraction & $25.288 \pm 1.502^{\mathrm{b}}$ & $55.468 \pm 2.768^{\mathrm{b}}$ \\
\hline
\end{tabular}

Values are expressed as mean $\pm \mathrm{SD}, \mathrm{n}=3$. Same alphabet superscripts within the same column indicate no significant difference ( $\mathrm{p}>0.05)$ which measured with Tukey's HSD test.

the methanol extract. These compounds can stop chain reactions of free radical by donating their electron to free radical compounds. The n-hexane fraction has a higher percentage of antioxidant activity than ethyl acetate fraction because n-hexane fraction has lipophilic compounds. Based on the research by Gali and Bedjou (2019), BCB assay has high specificity toward lipophilic compounds as these compounds can participate to stabilize the free radical. In Table 2, the percentage value of antioxidant activity statistically showed methanol extract, ethyl acetate fraction, n-hexane fraction and dichloromethane fraction did not have significant difference.

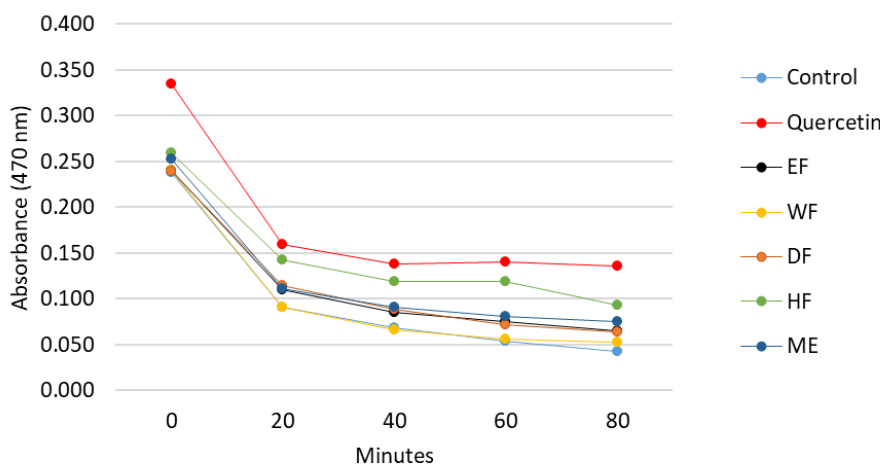

Figure 3. Degradation rate of various fraction of Baccaurea racemosa pulp assayed by $\beta$-carotene bleaching test. Quercetin is used to be a standard. N-hexane fraction (HK), dichloromethane fraction (DK), Ethyl Acetate Fraction (EF), Water Fraction (WF), Methanolic extract (ME). Values are expressed as means $\pm \operatorname{SD}(n=3)$.

\section{$3.4 T P C$ and $T F C$}

Flavonoids, including flavones, flavonols and catechins, are included class of phenolic compounds which contain hydroxyl groups (Afshar et al., 2012). These will destroy the free radical through donating their hydrogen atom to radical (Bajalan et al., 2017). Therefore, the quantification of TPC and TFC are important to determine the activity of antioxidant in plants. TPC and TFC were determined using gallic acid calibration curves $\left(\mathrm{Y}=109.65 \mathrm{x}+0.0276, \mathrm{r}^{2}=0.9927\right)$ and rutin calibration curves $\left(\mathrm{Y}=10.038 \mathrm{x}-0.0151, \mathrm{r}^{2}=\right.$ 0.9978). The data showed in Table 3 exhibited that ethyl acetate fraction had the highest TPC and TFC with $42.975 \pm 1.978 \mathrm{mg}$ GAE $\mathrm{g}^{-1}$ dry extract and $122.813 \pm 1.604 \mathrm{mg} R E \mathrm{~g}^{-1}$ dry extract respectively. Flavonoid, belonging to phenolic compounds, are soluble in ethyl acetate which resulted a high total flavonoid and phenolic contents in the ethyl acetate fraction. Their values were statistically significant different with other fraction.

The correlation of TPC and TFC with antioxidant activity displayed variation (Table 4). The TPC and TFC of various fraction of $B$. racemosa pulp have no significant correlation with their values of DPPH free radical scavenging activity and $\mathrm{BCB}$ which indicates that the DPPH free radical scavenging activity and $\mathrm{BCB}$ of $B$. racemosa were not influenced by their total phenolic and flavonoid content. $\beta$-carotene method has a high specificity on lipophilic compounds and therefore its antioxidant activity has low correlation with its total flavonoid and phenolic contents. Meanwhile, TPC and TFC have significant correlation with ABTS free radical scavenging activity with a correlation coefficient of 0.989 and 0.999 respectively. This results showed that the phenolic and flavonoid compounds of B. racemosa 
contributed highly to the ABTS free radical scavenging activity.

Table 4. Correlation coefficients between antioxidant activity and total phenolic and flavonoid content of $B$. racemosa pulp

\begin{tabular}{cccccc}
\hline & TPC & TFC & ABTS & DPPH & BCB \\
\hline TPC & 1 & 0.987 & $0.989^{* *}$ & -0.257 & 0.367 \\
TFC & & 1 & $0.999^{*}$ & -0.978 & 0.25 \\
ABTS & & & 1 & -0.357 & 0.249 \\
DPPH & & & & 1 & 0.202 \\
BCB & & & & & 1 \\
\hline
\end{tabular}

Values of correlation coefficient from Pearson correlation.

** Correlation is significant at the 0.01 level (2-tailed)

* Correlation is significant at the 0.05 (2-tailed)

\section{Conclusion}

This study evaluated the antioxidant activity of the extract and fractions of $B$. racemosa pulp. The partition of $B$. racemosa pulp with ethyl acetate was the best solvent to extract the compound with the highest antioxidant activity. This fruit had the potentiality as antioxidant that can be developed to be as a medicinal plant. The compounds in B. racemosa had the potential to scavenge the free radicals as well as to inhibit lipid peroxidation. The phenolic and flavonoid compounds contributed to the antioxidant activity of $B$. racemosa.

\section{Conflict of Interest}

Authors declare no conflict interest.

\section{Acknowledgement}

The authors Lina Permatasari, Sugeng Riyanto and Abdul Rohman thanks the financial support from Kementerian Riset, Teknologi, dan Pendidikan Tinggi Republik Indonesia (RISTEKDIKTI) through the scholarship of Program Magister menuju Doktor untuk Sarjana Unggul (PMDSU) with contract number 5836/ UN1.DITLIT/DIT-LIT/LT/2018.

\section{References}

Afshar, F.H., Delazar, A., Nazemiyeh, H., Esnaashari, S. and Moghadam, S.B. (2012). Comparison of the total phenol, flavonoid contents and antioxidant activity of methanolic extracts of Artemisia spicigera and A. splendens growing in Iran. Pharmaceutical Sciences, 18(3), 165-170.

Ahmed, I.A., Mikail, M.A., Bin Ibrahim, M., Bin Hazali, N., Rasad, M.S.B.A., Ghani, R.A., Wahab, R.A., Arief, S.J. and Yahya, M.N.A. (2015). Antioxidant activity and phenolic profile of various morphological parts of underutilised Baccaurea angulata fruit. Food Chemistry, 172, 778-787. https://doi.org/10.1016/j.foodchem.2014.09.122

Aktumsek, A., Zengin, G., Guler, G.O., Cakmak, Y.S. and Duran, A. (2013). Antioxidant potentials and anticholinesterase activities of methanolic and aqueous extracts of three endemic Centaurea L. species. Food and Chemical Toxicology, 55, 290296. https://doi.org/10.1016/j.fct.2013.01.018

Bajalan, I., Zand, M., Goodarzi, M. and Darabi, M. (2017). Antioxidant activity and total phenolic and flavonoid content of the extract and chemical composition of the essential oil of Eremostachys laciniata collected from Zagros. Asian Pacific Journal of Tropical Biomedicine, 7(2), 144-146. https://doi.org/10.1016/j.apjtb.2016.11.022

Cequier-Sánchez, E., Rodríguez, C., Ravelo, Á.G. and Zárate, R. (2008). Dichloromethane as a solvent for lipid extraction and assessment of lipid classes and fatty acids from samples of different natures. Journal of Agricultural and Food Chemistry, 56(12), 42974303. https://doi.org/10.1021/jf073471e

Cerretani, L. and Bendini, A. (2010). Rapid Assays to Evaluate the Antioxidant Capacity of Phenols in Virgin Olive Oil. In Preedy, V.R and Watson, R.R. (Eds.) Olives and Olive Oil in Health and Disease Prevention, p. 625-635. USA: Elsevier. https:// doi.org/10.1016/B978-0-12-374420-3.00067-X

Chang, C.-C., Yang, M.-H., Wen, H.-M. and Chern, J.-C. (2002). Estimation of total flavonoid content in propolis by two complementary colorimetric methods. Journal of Food and Drug Analysis, 10(3), $178-182$.

Chun, O.K., Kim, D.O. and Lee, C.Y. (2003). Superoxide radical scavenging activity of the major polyphenols in fresh plums. Journal of Agricultural and Food Chemistry, 51(27), 8067-8072. https:// doi.org/10.1021/jf034740d

Dey, P. and Pal, I. (2015). A glimpse on Baccaurea ramifolia, a less appealing, underutilized medicinal plant of west-bengal (an extensive review). International Journal of Current Research, 7(7), 18287-18295.

Fitri, N. (2013). Butylated hydroxyanisole sebagai bahan aditif antioksidan pada makanan dilihat dari perspektif kesehatan. Jurnal Kefarmasian Indonesia, $4(1), 41-50$.

Gali, L. and Bedjou, F. (2019). Antioxidant and anticholinesterase effects of the ethanol extract, ethanol extract fractions and total alkaloids from the cultivated Ruta chalepensis. South African Journal of Botany, 120, 163-169. https://doi.org/10.1016/ j.sajb.2018.04.011

Gunawan, G., Chimawati, T., Sobir. and Sulistijorini. (2016). Review: fitokimia genus baccaurea spp. Bioeksperimen: Jurnal Penelitian Biologi, 2(2), 96- 
110.

bioeksperimen.v2i2.2488

Hadi, S., Wahyuono, S., Yuswanto, A. and Lukitaningsih, E. (2015). Penelusuran fraksi aktif Baccaurea lanceolata dari Kabupaten Tapin, Kalimantan Selatan sebagai antioksidan. Pharmacy, 12(2), 242-246.

Ismail, N.H., Jaafar, F.M., Ahmat, N., Ahmad, R., Hussain, N.H. and Khamis, S. (2010). Phytochemical and biological activity screening of plants collected from Kuala Keniam, Taman Negara, Pahang, presented at National Biodiversity Seminar 2008. Kuala Lumpur, Malaysia: Department of Wildlife and National Parks.

Kikuzaki, H., Hisamoto, M., Hirose, K., Akiyama, K. and Taniguchi, H. (2002). Antioxidant properties of ferulic acid and its related compounds. Journal of Agricultural and Food Chemistry, 50(7), 2161-2168. https://doi.org/10.1021/jf011348w

Lobo, V., Patil, A., Phatak, A. and Chandra, N. (2010). Free radicals, antioxidants and functional foods: Impact on human health. Pharmacognosy Reviews, 4 (8), 118-126. https://doi.org/10.4103/09737847.70902

Maisarah, A.M., Amira, N., Asmah, R. and Fauziah, O. (2013). Antioxidant analysis of different parts of Carica papaya. International Food Reseach Journal, 20(3), 1043-1048.

Pham-Huy, L.A., He, H. and Pham-Huy, C. (2008). Free radicals, antioxidants in disease and health. International Journal of Biomedical Science: IJBS, 4 (2), 89-96.

Race, S. (2009). Antioxidants The Truth about BHA, BHT, TBHQ and other Antioxidants Used as Food Addictives. United Kingdom: Tigmor Books.

Tchimene, M.K., Nwaehujor, C.O., Ezenwali, M., Okoli, C.C. and Iwu, M. (2016). Free radical scavenging activity of lupeol isolated from the methanol leaf extract of Crateva adansonii Oliv. (Capparidaceae). International Journal of Pharmacognosy and Phytochemical Research, 8(3), 419-426.

Widyawati, P.S., Budianta, T.D.W., Kusuma, F.A. and Wijaya, L. (2015). Difference of Solvent polarity to phytochemical content and antioxidant activity of Pluchea indicia Less leaves extracts. International Journal of Pharmacognosy and Phytochemical Research, 6(4), 850-855.

Wulansari, D. and Chairul, C. (2011). Penapisan aktivitas antioksidan dan beberapa tumbuhan obat indonesia menggunakan radikal 2,2-diphenyl-1 picrylhydrazyl (DPPH). Majalah Obat Tradisional, 16(1), 22-25.
Zadak, Z., Hyspler, R., Ticha, A., Hronek, M., Fikrova, P., Rathouska, J., Hrnciarikova, D. and Stetina, R. (2009). Antioxidants and vitamins in clinical conditions. Physiological Research, 58(1), 13-17. 